\title{
Isolation of Amber Mutant of a P Group R Factor after Hydroxylamine Mutagenesis of a Transducing Lysate
}

\author{
By S. BAUMBERG \\ Department of Genetics, The University, Leeds $L S_{2}{ }_{9} J T$ \\ (Received 8 July 1975; revised I 8 December 1975)
}

INTRODUCTION

The technique, used in bacterial mutagenesis, of exposing a generalized transducing phage lysate to hydroxylamine was first described for the Salmonella typhimurium phage $\mathrm{P}_{22}$ by Hong \& Ames (1971), although it represents a variation on a principle long employed with transformation in Bacillus subtilis (e.g. Young, Smith \& Reilly, 1969). Hong \& Ames used the term 'localized mutagenesis' for the technique because of its usefulness in the isolation of mutations cotransducible with, and therefore close to, a given selected marker. This method of mutagenesis can be very efficient: for instance, when Escherichia coli KI 2 ppc $^{+}$transductants produced with a hydroxylamine-mutagenized PI lysate were screened for mutations in the adjoining $\operatorname{argECBH}$ cluster, about $0.6 \%$ were found to be arginine auxotrophs (Bretscher \& Baumberg, 1976). Other attractions of this technique are: (i) hydroxylamineinduced mutations apparently occur randomly rather than in clusters as with nitrosoguanidine, and (ii) recessive mutations are expressed without need for growth and segregation after transduction (Hong \& Ames, 197I). Its usefulness in isolating plasmid mutants was therefore tested.

\section{METHODS}

Bacterial, plasmid and phage strains. These are described in Table I. All bacteria were derivatives of $E$. coli $\mathrm{KI} 2$.

Media. Nutrient broth no. 2 and MacConkey agar were from Oxoid. Lennox broth (LB) was prepared according to Lennox (1955), with the addition of $2.5 \mathrm{mM}-\mathrm{CaCl}_{2}$. LB agar plates contained $\mathrm{I} \cdot 25 \%(\mathrm{w} / \mathrm{v})$ agar; LB soft agar contained $0.5 \%(\mathrm{w} / \mathrm{v})$ agar. Minimal salts medium and supplements were as described by Baumberg (1970). Ampicillin, kanamycin and tetracycline were used at 25,25 and $10 \mu \mathrm{g} \mathrm{ml}^{-1}$ respectively, unless otherwise noted.

Preparation and assay of $\mathrm{PI}$ kc lysates. LB soft agar $(2 \mathrm{ml})$, kept liquid in a $45^{\circ} \mathrm{C}$ bath, was inoculated with $10^{6}$ to $10^{8}$ phage particles and $2 \times 10^{7}$ to $2 \times 10^{8}$ cells from either a midexponential to early stationary phase shaken LB culture or an overnight unshaken LB culture, and the mixture was poured on to $\mathrm{LB}$ agar plates pre-warmed to $37^{\circ} \mathrm{C}$. The plates were incubated at $37^{\circ} \mathrm{C}$ for about $6 \mathrm{~h}$, after which the semi-liquid soft agar layer was allowed to solidify at room temperature. LB $(2 \mathrm{ml})$ was added, the soft agar macerated, and the whole was transferred to a test-tube for low-speed centrifuging. The supernatant lysate was stored at $4{ }^{\circ} \mathrm{C}$ over chloroform to maintain sterility. Lysates were assayed by the soft agar overlay method and those that contained $2 \times 10^{9}$ or more plaque-forming units (p.f.u.) $/ \mathrm{ml}$ were used in further experiments.

Mutagenesis of PIkc lysates. This followed the method of Hong \& Ames (1971). Lysate ( 5 to $\mathrm{I} 0 \mathrm{ml}$; titre at least $10^{10}$ p.f.u. $/ \mathrm{ml}$ ) was centrifuged at $38000 \mathrm{~g}$ for $90 \mathrm{~min}$ at $15{ }^{\circ} \mathrm{C}$, by 
Table 1. Bacterial, plasmid and phage strains

\begin{tabular}{|c|c|c|}
\hline Strain & Genotype & Origin \\
\hline \multicolumn{3}{|c|}{ Bacteria (Escherichia coli) } \\
\hline $\mathrm{J} 62-\mathrm{I}$ & $\mathrm{F}^{-}$pro his trp lac nal-r & N. Datta \\
\hline $\mathrm{CB}-\mathrm{I}$ & $\mathrm{Hfr}(\mathrm{P} 4 \mathrm{X}) m e t B \arg C B-I$ & N. Glansdorff \\
\hline $\mathrm{P} 4 \mathrm{X}$ & $\mathrm{Hfr}(\mathrm{P} 4 \mathrm{X}) \operatorname{met} B$ & N. Glansdorff \\
\hline P4XGN & $\begin{array}{l}\text { Spontaneous nal-r mutant of } \mathrm{P} 4 \mathrm{XG} \\
\mathrm{Hfr}(\mathrm{P} 4 \mathrm{X}) p p c\end{array}$ & A. E. Kadikiran \\
\hline $\mathrm{P} 4 \times \mathrm{BB} 2$ & $\mathrm{Hfr}(\mathrm{P} 4 \mathrm{X})$ met $B \arg R$ & N. Glansdorff \\
\hline $\begin{array}{l}\text { EI } 8 M \\
\text { E34M }\end{array}$ & $\left.\begin{array}{l}\operatorname{Hfr}(\mathrm{P} 4 \mathrm{X}) \arg E_{18} \\
\mathrm{Hfr}(\mathrm{P} 4 \mathrm{X}) \arg E_{34}\end{array}\right\}$ & $\begin{array}{l}\mathrm{Met}^{+} \text {transductants of strains } \\
\text { E1 } 8 \text { and E34 (Cunin et al., I969) }\end{array}$ \\
\hline TLAO2 & $\mathrm{F}-\operatorname{argC6} \operatorname{trp} l a c$ & N. Glansdorff \\
\hline $\begin{array}{l}\text { P4XB2EI } 8 \\
\text { P4XB2E34 }\end{array}$ & $\left.\begin{array}{l}\mathrm{Hfr}(\mathrm{P} 4 \mathrm{X}) \arg R \arg E_{I 8} \\
\mathrm{Hfr}(\mathrm{P} 4 \mathrm{X}) \arg R \arg E_{34}\end{array}\right\}$ & $\begin{array}{l}\text { Isolated among } \mathrm{Met}^{+} \text {transductants } \\
\text { of } \mathrm{P} 4 \mathrm{XB} 2 \text { with PI } k c \text { grown on EI } 8 \mathrm{M} \\
\text { or } \mathrm{E} 34 \mathrm{M}\end{array}$ \\
\hline P4XC6 & $\mathrm{Hfr}(\mathrm{P} 4 \mathrm{X}) \operatorname{argC6}$ & $\begin{array}{l}\text { Isolated among } \mathrm{Met}^{+} \text {transductants } \\
\text { of } \mathrm{P} 4 \mathrm{X} \text { with PI } k c \text { grown on TLAO2 }\end{array}$ \\
\hline $\begin{array}{l}\mathrm{c} 600 \\
\mathrm{c} 600 \mathrm{~N}\end{array}$ & $\begin{array}{l}\mathrm{F}^{-} \text {thr leu thi lac str-r suII } \\
\text { Spontaneous nal-r mutant of c } 600\end{array}$ & NCIBIO222 \\
\hline $\begin{array}{l}\text { Plasmid } \\
\text { RI } 822\end{array}$ & $\begin{array}{l}\text { Confers resistance to } \mathrm{A}, \mathrm{K}, \mathrm{T} \text {; } \\
\text { incompatibility group } \mathrm{P}\end{array}$ & R. H. Olsen \\
\hline \multicolumn{2}{|l|}{ Phages } & V. Bryson \\
\hline $\mathrm{N}_{58}$ & Amber mutant of phage $\mathrm{T}_{4}$ & J. R. Guest \\
\hline $\mathrm{C}_{427}$ & Ochre mutant of phage $\mathrm{T}_{4}$ & J. R. Guest \\
\hline PRRI & $\begin{array}{l}\text { RNA phage that infects cells } \\
\text { carrying } P \text { group plasmids }\end{array}$ & R. H. Olsen \\
\hline
\end{tabular}

* A, ampicillin; $\mathrm{K}$, kanamycin; $\mathrm{T}$, tetracycline. In descriptions of the phenotype of strains carrying this $R$ factor or its derivatives, superscripts $\mathbf{r}$ and $s$ denote resistance and sensitivity respectively.

which time over $99 \%$ of the phage had sedimented. The supernatant was removed, and mutagenesis mixture $(3 \mathrm{ml})$ was added to the pellet. The mutagenesis mixture contained (per $\mathrm{ml}$ ): $0.3 \mathrm{ml}$ phage buffer (Clowes \& Hayes, 1968); $0.6 \mathrm{ml} \mathrm{0.I} \mathrm{M-sodium} \mathrm{phosphate}$ buffer $\mathrm{pH} 6$, containing I mM-EDTA; and $0.1 \mathrm{ml}$ freshly prepared I M-hydroxylammonium chloride, adjusted to $\mathrm{pH} 6$ with $\mathrm{IO} \mathrm{M}-\mathrm{NaOH}$ and containing I mM-EDTA. The phage particles were gently resuspended in this mixture with a glass rod and incubated at $37^{\circ} \mathrm{C}$ for $40 \mathrm{~h}$. They were then centrifuged as above, washed twice with phage buffer, and finally resuspended in LB. The suspension was kept over chloroform till use. Sometimes the mutagenized phage became incapable of transduction after a few days' storage at $4{ }^{\circ} \mathrm{C}$, and so it was used as quickly as possible. During mutagenesis, the plaque-forming titre fell rapidly though to a variable extent, initially by as much as io-fold every $4 \mathrm{~h}$. Transducing ability was, however, relatively little affected. This was to be expected, since phage genomes rapidly accumulate mutations that render them incapable of productive infection.

Transduction procedure. Unmutagenized PI $k c$ at multiplicities of 0.0 I to 0.5 , or various quantities of mutagenized PI $k c$, were added to a late-exponential phase LB recipient culture. After incubating for $10 \mathrm{~min}$ at $37^{\circ} \mathrm{C}$, the mixtures, and controls without phage, were centrifuged and resuspended in minimal salts; both were then plated on selective media.

Testing of transductants. Transductants selected for resistance to one antibiotic were streaked on to two MacConkey agar plates each containing one of the other antibiotics to 
which RI822 confers resistance. Alternatively, antibiotic-sensitive transductants were sought by replica plating the selection plate directly on to MacConkey agar plates containing one of the other antibiotics. Both methods worked. Resistance to phage PRRI was checked either by spotting a high-titre suspension of PRRI on to a lawn of the isolate in soft agar on a nutrient agar base, or by spotting the phage on to a streak of culture on nutrient agar plates (surface spot test).

Conjugation procedure. A mid-exponential phase nutrient broth donor culture was mixed with an overnight nutrient broth recipient culture in the proportion $\mathrm{I}:$ Io by vol. The mixture was incubated at $37^{\circ} \mathrm{C}$ for $2 \mathrm{~h}$; it and its parental controls were then centrifuged, resuspended in minimal salts, diluted as appropriate and plated on selective media.

Isolation and testing of revertants. Overnight nutrient broth cultures of strains carrying a mutant Ri822 plasmid and an $\arg E$ or $\arg C$ amber mutation were centrifuged and resuspended in $0.5 \mathrm{vol}$. of minimal salts. Minimal plates lacking arginine were spread with the suspension $(0.05$ to $0.25 \mathrm{ml})$ and incubated for 3 to 5 days at $37^{\circ} \mathrm{C}$. Revertant colonies were picked directly into nutrient broth $(2 \mathrm{ml})$, grown overnight at $37^{\circ} \mathrm{C}$, and spot tested in soft agar with $\mathrm{T}_{4}$ amber mutant $\mathrm{N}_{58}, \mathrm{~T}_{4}$ ochre mutant $\mathrm{C}_{427}$, and PRRI.

\section{RESULTS AND DISCUSSION}

\section{Isolation of mutants of $R$ factor $\mathrm{R}_{1} 822$ after hydroxylamine mutagenesis of a transducing lysate}

Prkc lysates of strain $\mathrm{J} 62-\mathrm{I}$ carrying the $\mathrm{RI} 822$ plasmid were prepared, treated with hydroxylamine, and used to transduce strain CB-I. Transductants were selected on MacConkey agar containing either ampicillin, kanamycin or tetracycline, and also on minimal media supplemented with either methionine or arginine, so that frequencies of transduction of plasmid markers could be compared with those of chromosomal markers. For unknown reasons, no transductants ever appeared on kanamycin at $25 \mu \mathrm{g} \mathrm{ml}^{-1}$, although a few appeared when the concentration was lowered to $10 \mu \mathrm{g} \mathrm{ml}^{-1}$. Relative numbers of transductants inheriting the various selected markers $\mathrm{A}^{\mathrm{r}}: \mathrm{K}^{\mathrm{r}}: \mathrm{T}^{\mathrm{r}}: \mathrm{Arg}^{+}: \mathrm{Met}^{+}$were approximately I0:I: $10: 200: 100$ for untreated lysates; after treatment of the lysate with hydroxylamine, the ratio of $\mathrm{Arg}^{+}$and $\mathrm{Met}^{+}$to $\mathrm{A}^{\mathrm{r}}$ and $\mathrm{T}^{\mathrm{r}}$ increased by a factor of 5 to $\mathrm{IO}$. The untreated lysate gave one $\mathrm{Arg}^{+}$transductant per $\mathrm{I} \cdot 4 \times 10^{5}$ p.f.u. The equivalent figure cannot be given for the hydroxylamine-treated lysate, since little or no plaque-forming ability remained. However, assuming that the centrifugations before and after mutagenesis pelleted $100 \%$ of the particles and that the final resuspension separated them completely, one would expect a frequency of one $\mathrm{Arg}^{+}$transductant per $6.7 \times 10^{5}$ p.f.u. in the untreated lysate.

A total of $273 \mathrm{~A}^{\mathrm{r}}$ and $403 \mathrm{~T}^{\mathrm{r}}$ transductants isolated from lysates exposed to hydroxylamine, together with $198 \mathrm{~A}^{\mathrm{r}}$, I6 $\mathrm{K}^{\mathrm{r}}$ and $\mathrm{I} 47 \mathrm{~T}^{\mathrm{r}}$ transductants obtained with an untreated control lysate, were tested for cotransduction of other plasmid markers. Among the former were found one $A^{8}$, one $K^{8}$ and two $T^{8}$ mutants, and 17 that failed to give a positive surface spot test with phage PRRI. No variants were found among the transductants obtained with the untreated lysate. The frequency of mutants among the transductants isolated using hydroxylamine-treated transducing phage was therefore $21 / 676$ or $3 \%$, for the limited number of markers examined.

Strains carrying the four mutant plasmids that failed to confer resistance to one of the three antibiotics all retained resistance to the other pair of antibiotics and the plasmids were transmissible to strain P4XGN. However, although fertility was normal for the $A^{s}$ and $K^{s}$ mutants, the two $T^{\mathrm{s}}$ mutant plasmids showed diminished transmissibility and, unlike the $\mathrm{A}^{\mathrm{s}}$ 
and $\mathrm{K}^{\mathrm{s}}$ mutants, gave weak or negative PRR 1 spot tests in soft agar. The reason for this is not known. The plasmid phenotypes were the same in P4XGN as in CB-I, confirming that mutations were carried on the plasmid. The phenotype of the $A^{s}$ mutant was interesting in that sensitivity to ampicillin was not completely lost; in this respect the mutant resembles that described by Curtis, Richmond \& Stanisich (1973). The $\mathrm{A}^{\mathrm{s}}$ isolate, when plated on MacConkey agar containing ampicillin at 10,25 , and $50 \mu \mathrm{g} \mathrm{ml}^{-1}$, gave approximately 100,1 and $0.01 \%$ survival respectively at the three concentrations.

The 17 mutants that failed to give a positive surface spot test with PRRI also failed to do so in soft agar; all carried the complete set of wild-type antibiotic resistances and were non-transmissible. As CB-I, the recipient strain for the transduction with mutagenized phage, is $\mathrm{Hfr}$, it would appear that the mutant $\mathrm{R} 1822$ plasmids cannot be mobilized by F. In view of the specificity of mobilization of non-transmissible plasmids sometimes observed (see, for example, Williams Smith \& Heller, 1973), this is not perhaps especially surprising. I shall denote the mutations in these mutant plasmids as $\mathrm{tra}^{-}$.

\section{Characterization of amber mutants of $\mathrm{R} 1822$}

In order to detect whether any of the plasmid mutations were of the amber or ochre chain-terminating types, $\arg E$ or $\arg C$ amber mutations were introduced into the isolates and co-reversion (indicating suppression) looked for. Each of the 2I mutants was used as recipient in crosses with strains P4XB2E18, P4XB2E34, or P4XC6 as donor, and selection was made for Met ${ }^{+}$transconjugants (arginine being present in the selective medium) that retain the antibiotic resistances conferred by the plasmid concerned. Transconjugants were tested for the presence of the known amber mutations $\operatorname{argE18}, \arg E 34$ or $\arg C 6$ by plating them on medium containing ornithine. Recombinants with any of these amber arg mutations grew well on orthinine, whereas those retaining $\arg C B-1$, which is a polar deletion, show only poor growth (Cunin et al., 1969). Since the met $B$ marker in CB-I is closely linked to the $\operatorname{argECBH}$ cluster, the great majority of Met transconjugants were of the type sought.

$\mathrm{Tra}^{-}$strains carrying a mutant plasmid and an arg amber mutation were grown in nutrient broth and spontaneous $\mathrm{Arg}^{+}$revertants selected. Five to ten revertants were then tested for spot lysis by $\mathrm{N}_{5} 8, \mathrm{C}_{42} 7$ and PRRI in soft agar. Of five tra $^{-}$mutant plasmids examined in this way with the three arg amber mutations, one, tra-3, was found to yield a positive PRRI spot test when combined with the $\operatorname{argC6}$ and $\mathrm{Arg}^{+}$revertants tested; furthermore, revertants that gave a positive spot test with PRRI also gave positive spot tests with one or other or both of the $\mathrm{T}_{4}$ nonsense mutants $\mathrm{N}_{5} 8$ and $\mathrm{C}_{427}$. The $\mathrm{R}$ factor was transmissible from these revertants to P4XGN. However, P4XGN carrying that $\mathrm{R}$ factor failed to give a positive spot test in soft agar with PRRI and the $\mathrm{R}$ factor was not transmissible. Both observations suggest that the $\mathrm{Arg}^{+} \mathrm{Tra}^{+}$phenotype in the revertants was due to amber or ochre suppressors. From one of these revertants, tra-3 was transferred to 6600 , which carries the amber suppressor suII. In this host it conferred a weak sensitivity to phage PRRI in soft agar, and was transmissible, though at a lower frequency than the parental RI822. The frequency of transfer to strain $\mathrm{C} 600 \mathrm{~N}$ was $8 \times 10^{-7}$ to $3.5 \times 10^{-6}$ per donor cell, compared with $1 \cdot 4 \times 10^{-4}$ for $\mathrm{R}_{1} 822$. It appears that suII suppresses $t r a-3$ rather inefficiently: this may be due to a low frequency of suppression or to the glutamine inserted by suII not allowing optimal function of the polypeptide whose gene has suffered an amber mutation in tra-3. The latter would seem more probable since suII is known to be a relatively efficient suppressor (Kaplan, Stretton \& Brenner, 1965).

Similar attempts were made to discover whether any of the four antibiotic-sensitivity mutations were amber or ochre. As yet there is no evidence for this. 
In view of the remarkably wide host range of Ri 822 (Olsen \& Shipley, I973), the amber mutant described here may be useful in identifying amber or ochre mutations in these diverse bacterial species.

The technical assistance of Frank Dooley and Mrs Margaret Lovett is gratefully acknowledged, as is the provision of cultures by Drs Datta, Glansdorff, Guest and Olsen. I also wish to thank the members of the Microbiology $4 \mathrm{~A} / 4 \mathrm{BY}$ class of $1973-4$ for isolating some of the $\mathbf{R}$ factor mutants.

\section{REFERENCES}

BAUMBerg, S. (1970). Acetylhistidine as substrate for acetylornithinase: a new system for the selection of arginine regulation mutants in Escherichia coli. Molecular and General Genetics 106, I62-1 73.

Bretscher, A. P. \& BaUmberg, S. (1976). Divergent transcription of the argECBH cluster of Escherichia coli $\mathrm{KI}$ 2. Journal of Molecular Biology (in the Press).

Clowes, R. C. \& Hayes, W. (1968). Experiments in Microbial Genetics. Oxford: Blackwell Scientific Publications.

Cunin, R., Elseviers, D., Sand, G., Freundlich, G. \& Glansdorff, N. (1969). On the functional organization of the argECBH cluster of genes in Escherichia coli KI 2. Molecular and General Genetics 106, $32-47$.

Curtis, N. A. C., Richmond, M. H. \& Stanisich, V. (1973). R-factor mediated resistance to penicillins which does not involve a $\beta$-lactamase. Journal of General Microbiology 79, 163-1 66.

HoNG, J. \& AmEs, B. N. (1971). Localized mutagenesis of any specific small region of the bacterial chromosome. Proceedings of the National Academy of Sciences of the United States of America 68, 31 58-3162.

Kaplan, S., Stretton, A. O. W. \& Brenner, S. (1965). Amber suppressors: efficiency of chain propagation and suppressor specific amino acids. Journal of Molecular Biology I4, 528-533.

LenNox, E. S. (1955). Transduction of linked genetic characters of the host by bacteriophage PI. Virology $\mathbf{r}$, I90-206.

Olsen, R. H. \& Shipley, R. (1973). Host range and properties of the Pseudomonas aeruginosa R factor Ri 822. Journal of Bacteriology 113, 772-780.

Williams Smith, H. \& HelleR, E. D. (I973). The activity of different transfer factors introduced into the same plasmid-containing strain of Escherichia coli $\mathbf{x 1 2}$. Journal of General Microbiology 78, 89-99.

Young, F. E., Smith, C. \& Reilly, B. E. (1969). Chromosomal location of genes regulating resistance to bacteriophage in Bacillus subtilis. Journal of Bacteriology 98, 1087-1097. 